Research Paper

\title{
Effects of Matrix Stiffness on the Morphology, Adhesion, Proliferation and Osteogenic Differentiation of Mesenchymal Stem Cells
}

Meiyu Sun, Guangfan Chi, Pengdong Li, Shuang Lv, Juanjuan Xu, Ziran Xu, Yuhan Xia, Ye Tan, Jiayi Xu, Lisha $\mathrm{Li}^{\bowtie}$ and Yulin $\mathrm{Li}^{\bowtie}$

The Key Laboratory of Pathobiology, Ministry of Education, Norman Bethune College of Medicine, Jilin University, 130021, People's Republic of China

$\triangle$ Corresponding authors: Lisha Li: lilisha@jlu.edu.cn; Tel.: +86-139-4400-3580 and Yulin Li: ylli@jlu.edu.cn; Tel.: +86-139-0431-2889

(c) Ivyspring International Publisher. This is an open access article distributed under the terms of the Creative Commons Attribution (CC BY-NC) license (https://creativecommons.org/licenses/by-nc/4.0/). See http://ivyspring.com/terms for full terms and conditions.

Received: 2017.06.25; Accepted: 2017.12.21; Published: 2018.01.15

\begin{abstract}
BMMSCs have drawn great interest in tissue engineering and regenerative medicine attributable to their multi-lineage differentiation capacity. Increasing evidence has shown that the mechanical stiffness of extracellular matrix is a critical determinant for stem cell behaviors. However, it remains unknown how matrix stiffness influences MSCs commitment with changes in cell morphology, adhesion, proliferation, self-renewal and differentiation. We employed fibronectin coated polyacrylamide hydrogels with variable stiffnesses ranging from 13 to $68 \mathrm{kPa}$ to modulate the mechanical environment of BMMSCs and found that the morphology and adhesion of BMMSCs were highly dependent on mechanical stiffness. Cells became more spread and more adhesive on substrates of higher stiffness. Similarly, the proliferation of BMMSCs increased as stiffness increased. Sox 2 expression was lower during $4 \mathrm{~h}$ to 1 week on the $13-16 \mathrm{kPa}$ and $62-68 \mathrm{kPa}$, in contrast, it was higher during $4 \mathrm{~h}$ to 1 week on the $48-53 \mathrm{kPa}$. Oct4 expression on 13-16 kPa was higher than 48-53 $\mathrm{kPa}$ at $4 \mathrm{~h}$, and it has no significant differences at other time point among three different stiffness groups. On 62-68 kPa, BMMSCs were able to be induced toward osteogenic phenotype and generated a markedly high level of RUNX2, ALP, and Osteopontin. The cells exhibited a polygonal morphology and larger spreading area. These results suggest that matrix stiffness modulates commitment of BMMSCs. Our findings may eventually aid in the development of novel, effective biomaterials for the applications in tissue engineering.
\end{abstract}

\section{Introduction}

BMMSCs are of great interest for biomedical research, drug discovery, and cell-based therapies as they are capable of differentiating into neurogenic, adipogenic, myogenic, and osteogenic lineages [1-3]. The fate of the stem cells is influenced by the microenvironment in which they reside [4]. Although extensive efforts are devoted to identifying biochemical factors that mimic the stem cell microenvironment to maintain the stem status and to promote the differentiation if necessary, it is still a challenge to optimize new biomolecules supporting stem cell differentiation and/or producing a high level of desired lineages from the stem cells. Thus, intense efforts have been dedicated to the identification of physical contributors in the regulation of stem cell behaviors [5-7].

It is increasingly clear that cells respond to the mechanical surroundings. Cells spread more on stiffer matrix $[8,9]$, and migrate towards the area of higher modulus $[9,10]$. Adhesion [8], tyrosine signalling [11], and proliferation [12, 13] of fibroblasts, smooth muscle cells, and chondrocytes are regulated by the substrate stiffness. In a recent study, Engler et al. reported that BMMSCs differentiate into tissue specific lineages dependent on the stiffness of the supporting substrates when BMMSCs were cultured on matrixes mimicking the stiffness of brain $(0.1-1$ $\mathrm{kPa})$, muscle $(8-17 \mathrm{kPa})$ and pre-mineralized bone 
(25-40 kPa) [6]. However, it remains unclear how matrix stiffness influences BMMSCs lineage specificity on cell morphology, adhesion, and proliferation.

Polyacrylamide hydrogels, whose mechanical properties can be managed by the level of cross-linking and tuned within the physiologically relevant regime from several hundred Pascal (brain) to thousands of Pascal ( $\mathrm{kPa}$, arties), are widely used as substrates for stem cell culture [14]. The surface chemistry of the gel remains unchanged while its mechanical properties are altered [14, 15]. The porosity of the gels enables the flow of the medium. These properties of the gels provide a more natural environment than do conventional culture models, such as glasses or plastic substrates [16]. In this study, we employed fibronectin-coated polyacrylamide hydrogels cross-linked to various degrees to modify the mechanical microenvironment and to assess how BMMSCs respond to matrix stiffness in terms of morphology, adhesion, proliferation, self-renewal and osteogenic differentiation.

\section{Materials and Methods}

\section{Cell culture and characterization}

Primary BMMSCs were isolated from the bone marrow of young male C57BL/6J mice under ethical approval and maintained in an expansion medium (DMEM-F12; Gibco, USA) consisting of $10 \%$ fetal bovine serum (Gibco) supplemented with $1 \%$ penicillin/streptomycin (Beijing Dingguo Changsheng Biotechnology, China) and $10 \mathrm{ng} / \mathrm{ml}$ of basic fibroblast growth factor (PeproTech, USA). All experimental procedures were approved by the ethics committee of Jilin University and conformed to the regulatory standards. Isolated MSCs were characterized by the expression of surface markers through flow cytometric analysis and immunofluorescence assays. The multipotency of the BMMSCs differentiated into mesenchymal lineages, including adipocytes and osteoblasts, was confirmed before the cells were used for the following experiments. The osteogenic differentiation of BMMSCs was induced in osteogenic medium containing $0.1 \mu \mathrm{mol} / \mathrm{L}$ dexamethasone, $10 \mathrm{mmol} / \mathrm{L}$ b-glycerophosphate, 50 $\mu \mathrm{g} / \mathrm{mL}$ ascorbic acid, and $10 \mathrm{nM}$ vitamin D3. The differentiation of BMMSCs into adipocytes was induced in adipogenic medium containing $1 \mu \mathrm{M}$ dexamethasone, $10 \mu \mathrm{g} / \mathrm{mL}$ insulin, $100 \mu \mathrm{g} / \mathrm{mL}(0.45$ $\mathrm{mM}$ ) IBMX and $0.1 \mathrm{mM}$ indomethacin. The differentiation-inducing medium was changed every 2 days. BMMSCs were used at passage 3 for all experiments.

\section{Oil red $O$ and Alizarin red Staining}

For evaluation of lipid droplets, cells were fixed with $4 \%$ paraformaldehyde for 10 minutes and stained with oil red O (Dalian Meilun Biotech Co., Ltd, China) for $10 \mathrm{~min}$ at room temperature. For characterization of mineralized matrix, cells were fixed with $3.7 \%$ paraformaldehyde and stained with $1 \%$ of Alizarin Red S solution (Dalian Meilun Biotech Co., Ltd, China) in water for 10-15 minutes at room temperature. The cells were observed under inverted phase contrast microscope.

For characterization of mineralized matrix, cells were fixed with $3.7 \%$ paraformaldehyde and stained with $1 \%$ of Alizarin Red S solution (Dalian Meilun Biotech Co., Ltd, China) in water for 10-15 minutes at room temperature. The cells were observed under inverted phase contrast microscope.

\section{Flow cytometric analysis and immunofluorescence}

Expression of surface markers of BMMSCs was determined by using flow cytometry and immunofluorescence staining. Cells were collected and washed with PBS for three times and fixed with $4 \%$ polyformaldehyde for $20 \mathrm{~min}$. The cells were then blocked with 1\% BSA in PBS for $30 \mathrm{~min}$, incubated with $10 \mu \mathrm{g} / \mathrm{ml}$ anti-CD29, CD34, CD44, or CD45 mAbs (eBioscience, USA) for $1 \mathrm{~h}$.

\section{Gene expression analysis}

The same amount of total RNA was used to synthesize the first strand cDNA using Primescript RT reagent kit. PCR thermal profile consisted of $95^{\circ} \mathrm{C}$ for 5 minutes, followed by 40 cycles of $94^{\circ} \mathrm{C}$ for 30 seconds, $60{ }^{\circ} \mathrm{C}$ for 30 seconds and $72{ }^{\circ} \mathrm{C}$ for 30 seconds, $72^{\circ} \mathrm{C}$ for further extension. Primer sequences for the amplification are shown in Table 1.

Quantitative real-time reverse transcription polymerase chain reaction (qRT-PCR) was used to determine relative gene expression in osteogenic specific genes. Total RNA was extracted using TRI reagent (Sigma-Aldrich, St. Louis, MO, USA) according to the manufacturer's instructions. The same amount of total RNA was used to synthesize the first strand cDNA using Primescript RT reagent kit. PCR thermal profile consisted of $95^{\circ} \mathrm{C}$ for 10 minutes, followed by 40 cycles of $95^{\circ} \mathrm{C}$ for 15 seconds, $60^{\circ} \mathrm{C}$ for 1 minute. Genes were normalized to the housekeeping gene GAPDH and fold differences were calculated using the comparative $\mathrm{Ct}$ method. The osteogenic markers RUNX2, ALP, COL1A1, Osteopontin, and Osteocalcin were analyzed. Primers for the qRT-PCR were obtained from Sangon Biotech (Shanghai). Primer sequences for the amplification are shown in Table 1. 
Table 1. Primers used for the quantification of markers

\begin{tabular}{|c|c|c|}
\hline Gene name & Forward (5’ $-3^{\prime}$ ) & Reverse (5' $-3^{\prime}$ ) \\
\hline Osteocalcin & AGCAGCTTGGCCCAGACCTA & TAGCGCCGGAGTCTGTTCACTAC \\
\hline RUNX2 & CACTGGCGGTGCAACAAGA & TTTCATAACAGCGGAGGCATTTC \\
\hline ALP & TGCCTACTTGTGTGGCGTGAA & TCACCCGAGTGGTAGTCACAATG \\
\hline Osteopontin & TCCAAAGCCAGCCTGGAAC & TGACCTCAGAAGATGAACTC \\
\hline COL1A1 & CCCAAGGAAAAGAAGCACGTC & ACATTAGGCGCAGGAAGGTCA \\
\hline PPAR $\gamma 2$ & TTCGGAATCAGCTCTGTGGA & CCATTGGGTCAGCTCTTGTG \\
\hline AP2 & AGCATCATAACCCTAGATGG & GAAGTCACGCCTTTCATAAC \\
\hline $\mathrm{C} / \mathrm{EBP} \alpha$ & TTTGAGTCTGTGTCCTCACC & CACAACTCAGCTTTCTGGTC \\
\hline Sox 2 & CGGGAAGCGTGTACTTATCCTT & GCGGAGTGGAAACTTTTGTCC \\
\hline Oct4 & CAGGGCTTTCATGTCCTGG & AGTTGGCGTGGACTTTGC \\
\hline GAPDH & CATGGCCTTCCGTGTTCCTA & ССТGСТTCAССАССТTСТTGAT \\
\hline
\end{tabular}

\section{Fabrication of polyacrylamide substrates with varying stiffness}

Tunable polyacrylamide substrates were prepared as reported previously [16]. Briefly, glass coverslips were treated with 3-aminopropyltrimethoxysilane and $0.5 \%$ glutaraldehyde. Solution of $8 \%$ acrylamide (Sigma, USA) and varying concentrations of bis-acrylamide $(0.1 \%, 0.5 \%$, and $0.7 \%)$ (Sigma, USA) were mixed. Polymerization was initiated with $\mathrm{N}, \mathrm{N}, \mathrm{N}^{\prime}, \mathrm{N}^{\prime}$-tetramethylethylenediamine (TEMED) and ammonium persulfate (Sigma, USA). Then $0.2 \mathrm{mg} / \mathrm{ml}$ N-sulfosuccinyimidyl-6-(4'-azido-2'-nitrophenylamin o) hexanoate (sulfo-SANPAH) (Thermo, USA) dissolved in $10 \mathrm{mM}$ HEPES ( $\mathrm{pH}$ 8.5) was applied to cover the polyacrylamide gel and exposed to $365 \mathrm{~nm}$ ultraviolet light for 70 minutes for photoactivation in 24-well plates. The polyacrylamide sheet was washed three times with phosphate buffered saline (PBS) to remove excess reagent and incubated with fibronectin solution ( $1 \mu \mathrm{g} / \mathrm{cm} 2$; Sigma, USA) each well overnight at $4^{\circ} \mathrm{C}$. Before cells were plated, the polyacrylamide substrates were soaked in PBS and then in DMEM at $4^{\circ} \mathrm{C}$. The Young's modulus of polyacrylamide hydrogels was quantified using a biomechanical testing machine under contact load at a strain rate of $0.5 \mathrm{~mm} / \mathrm{s}$.

\section{Microscopy and imaging analysis of cell and matrix morphology}

The morphologic changes of BMMSCs were observed and photos were taken by an inverted phase contrast microscope at 4, 24, 72h and 1 week after seeding on polyacrylamide substrates. The major and minor axes of the cells were computed from the moments up to the second order of the thresholded binary image of the cell using NIH ImageJ; the aspect ratio of the cell is the ratio of major to minor axis.

For SEM imaging, after being washed three times in PBS, matrices were fixed with $1 \%$ glutaraldehyde solution in $0.1 \mathrm{M}$ cacodylate buffer $\left(\mathrm{pH}\right.$ 7.2) at $4^{\circ} \mathrm{C}$ for 3 days. By removing the glutaraldehyde with PBS, fixed cells were dehydrated in gradient ethanol and then ester exchanged with isoamyl acetate. Finally, these matrices were critical point-dried with $\mathrm{CO}_{2}$ [17].

\section{Cell adhesion assays}

For the analysis of cell adhesion, $1.0 \times 104$ cells/cm2 were seeded each well in a 24-well plate and allowed to attach for 24 hours. Then, the cells were washed 3 times with PBS to remove nonadherent cells, followed by addition of $4 \%$ paraformaldehyde for 10 minutes. The cells were then washed with PBS for three times. After incubation for 5 minutes with Hoechst, attached cells were observed with a fluorescent inverted phase contrast microscope.

\section{EdU cell proliferation assay}

Cell proliferation was further analyzed using Cell-Light $^{\mathrm{TM}}$ EdU DNA Cell Proliferation Kit (Ribobio, Guangzhou, China) according to the manufacturer's manual after 72 hours. Briefly, cells were re-suspended in fresh pre-warmed $\left(37^{\circ} \mathrm{C}\right)$ complete medium, counted and plated at a density of $3 \times 104$ cells $/ \mathrm{ml}$ onto 24 -well plate, in which gel slides had been placed.24 hours later, cell culture medium was replaced with medium containing EdU, and the cells were incubated for additional 2 hours. Then the cells were fixed, exposed to Apollo ${ }^{\circledR}$ reaction cocktail, and analyzed with electronic fluorescent microscopy.

\section{Statistical analysis}

Data were expressed as mean \pm standard deviation. Statistical analyzes were performed using the statistics package SPSS 13.0 (SPSS, Chicago, IL, USA). Comparison among all groups was carried out using independent-samples t-test. Differences were considered as significant at $\mathrm{P}<0.05$.

\section{Results}

\section{The characteristics of BMMSCs}

To confirm the characteristics of the BMMSCs in our system, we cultured the BMMSCs with a standard method. After 1 week of primary culture, BMMSCs 
adhered to culture dishes and exhibited polygonal shapes with limited spreading areas (Fig.S1A). The passage 2 BMMSCs displayed as long spindle-shaped fibroblastic cells with large nucleus and abundant cytoplasm (Fig.S1A). The passage 3 cells principally formed bipolar spindle-like cells, which were consistent with typical morphology (Fig.S1A). When the confluence reached $90 \%$, cells exhibited as spiral shape (Fig.S1A). These cells were used in our following experiments. Both flow cytometry and immunofluorescence staining analyses showed that BMMSCs at passage 3 were strongly positive for BMMSCs markers, such as CD44, CD73 and CD90, and negative for CD34 and CD45 (Figure S1B and C). Furthermore, the isolated BMMSCs displayed the potential to differentiate into adipogenic and osteogenic lineages after treatment with the respective induction factors. Cells induced with adipogenic medium contained numerous Oil-Red-O-positive lipid globules at the end of 2 weeks (Fig. S1D). Expression of adipocytic makers, such as AP2, PPARY2, and C/EBPa was evidenced (Fig. S1E). Similarly, dense cell packing and calcium deposits stained by Alizarin red were found in osteogenic BMMSCs after 3 weeks of cultivation (Fig. S1D).
Expressions of osteoblastic makers RUNX2 and Osteocalcin were confirmed (Fig. S1E). Together, our results demonstrated that the BMMSCs used in current study were indeed multipotent and responsive to differential stimuli.

\section{Stiffness measurement}

The mechanical properties of polyacrylamide can be easily modified by altering the density of cross-links in the gel. Increasing the concentration of either the amount of acrylamide monomer or bis-acrylamide cross-linker resulted in a gel with a higher Young's modulus after polymerization [18]. By adjusting the concentration of monomer- and/or bis-acrylamide, we made 3 gels with different stiffness values ranging from $13-16$ to $62-68 \mathrm{kPa}$ (Fig. 1A). Under the assay of SEM, the gel surface was flat and no aperture was observed in the $13-16 \mathrm{kPa}$. However, multiple small apertures were displayed in the 48-53 $\mathrm{kPa}$ and $62-68 \mathrm{kPa}$ gels (Fig. 1B). When $0.2 \mathrm{mg} / \mathrm{ml}$ fibronectin was added on the top of the gel, the surface remained flat and the small apertures were merged with fibronectin, which was later approved to be fit for the cell culture (Fig. 1B).
A

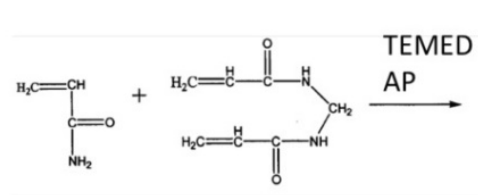

acrylamide bisacrylamide

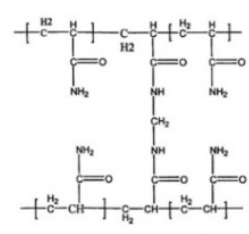

polyacrylamide

\begin{tabular}{lll}
\hline Acrylamide & Bis-acrylamide & Stiffness \\
\hline $8 \%$ & $0.1 \%$ & $13-16 \mathrm{kPa}$ \\
$8 \%$ & $0.5 \%$ & $48-53 \mathrm{kPa}$ \\
$8 \%$ & $0.7 \%$ & $62-68 \mathrm{kPa}$ \\
\hline
\end{tabular}

B
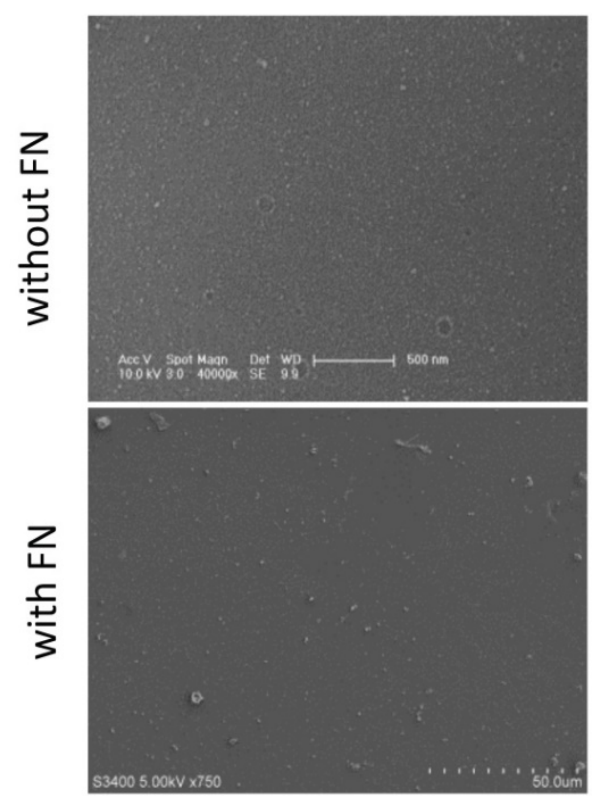

13-16 kPa
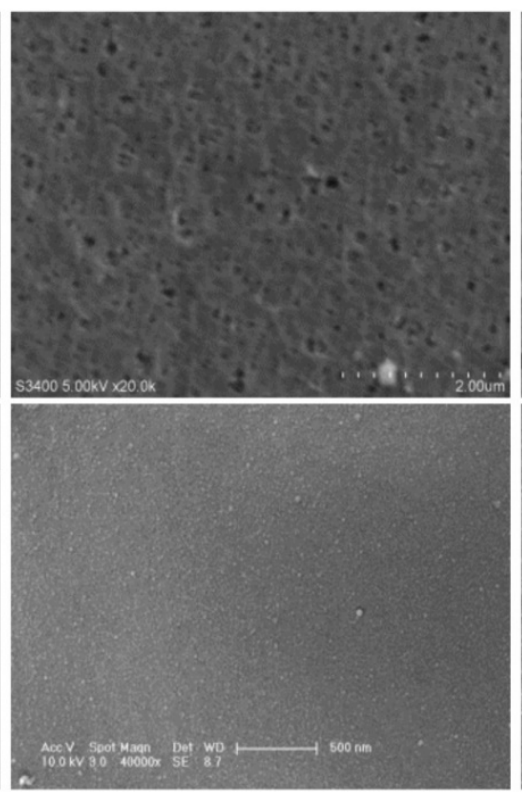

48-53 kPa

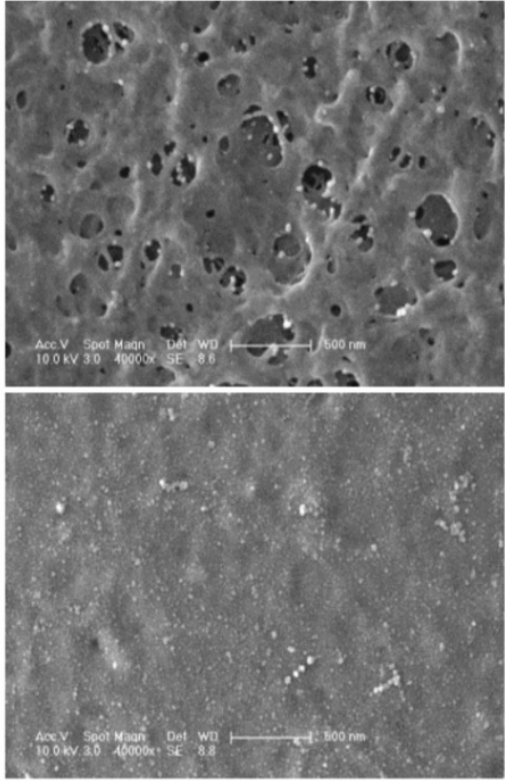

$62-68 \mathrm{kPa}$

Figure 1. Characteristics of polyacrylamide hydrogels. (A) $8 \%$ acrylamide, with a variety of concentrations of bis-acrylamide gel were used to make gels of different stiffnesses. (B) The polyacrylamide hydrogels of different stiffnesses were then topped with/without $0.2 \mathrm{mg} / \mathrm{ml}$ fibronectin and analyzed with SEM. 


\section{The characteristics of BMMSCs morphological changes on substrate with different stiffnesses}

To determine the impact of different stiffnesses on the growth of BMMSCs, we first detected the morphology of the cultured BMMSCs on the polyacrylamide gels. On a gel with stiffness of 13-16 $\mathrm{kPa}$, the cells displayed oval and short spindle shapes with pseudopodia after $4 \mathrm{~h}$ of inoculation. With the extension of pseudopodia, the cells exhibited an increasingly branched, filopodia-rich morphology 1 week after plantation (Fig.2A). Short shuttle-like cells gradually spread out in both ends and acquired a more stretched or elongated shape similar to that of myoblasts after 1 week on matrices with stiffnesses of $48-53 \mathrm{kPa}$. On $62-68 \mathrm{kPa}$ gel culture, the pseudopodia of cells stretched out and appeared to be triangular after 4 hours. A wide stretch of pseudopodia spread and the quantity of pseudopodia increased. 1 week later, the cells exhibited affluent pseudopodia and showed polygonal shapes similar to osteoblasts in morphology. In addition, we quantified the morphological changes by measuring the extent of cell elongation versus stiffness (aspect ratio, an indicator for the elongated cell shapes) and found that there was a highest aspect ratio at $48-53 \mathrm{kPa}$ gels, whereas BMMSCs on 13-16 $\mathrm{kPa}$ and $62-68 \mathrm{kPa}$ gels possessed a low aspect ratio at $4 \mathrm{~h}, 24 \mathrm{~h}, 72 \mathrm{~h}$ and 1 week (Fig. 2B). A time-course effect was observed for aspect rations in 48-53 kPa gel (Fig. 2C).

A

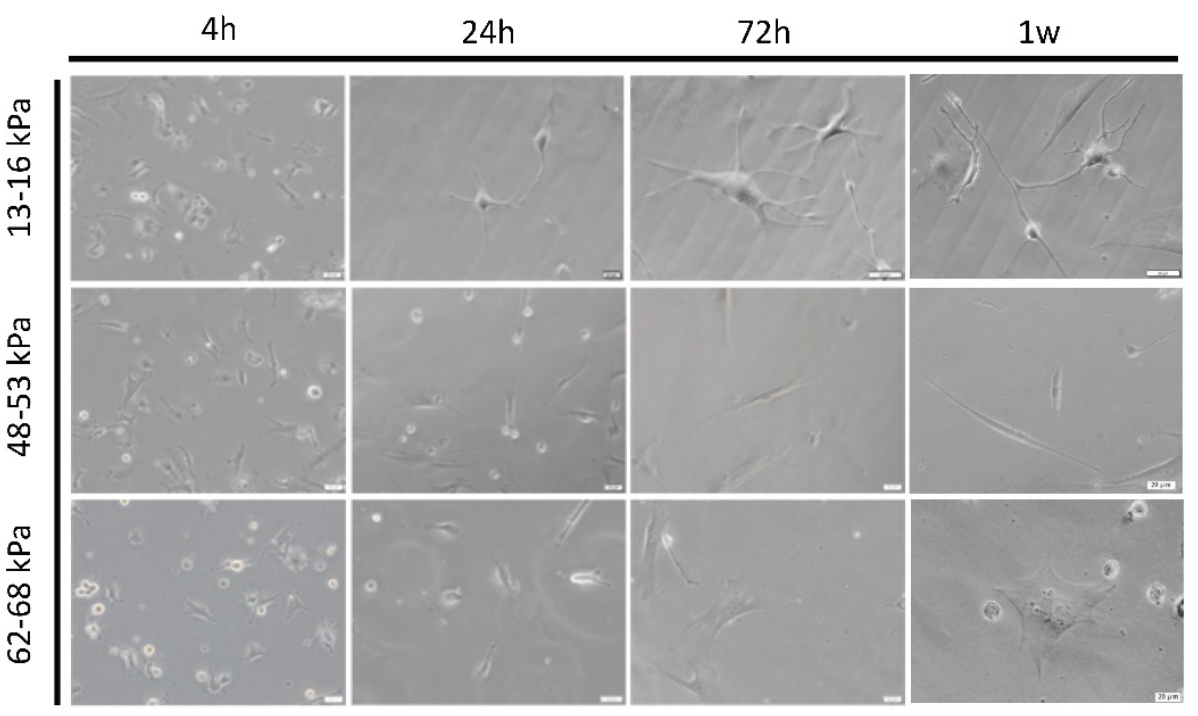

B

4h

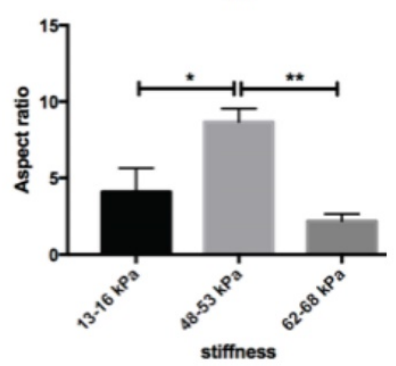

C

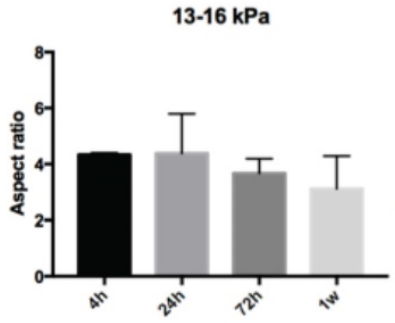

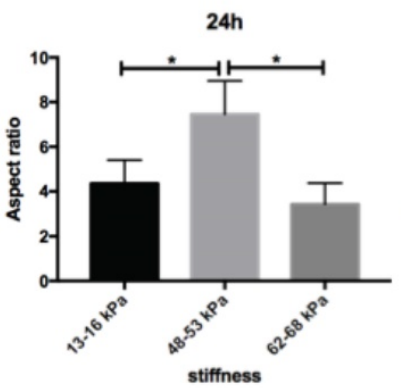
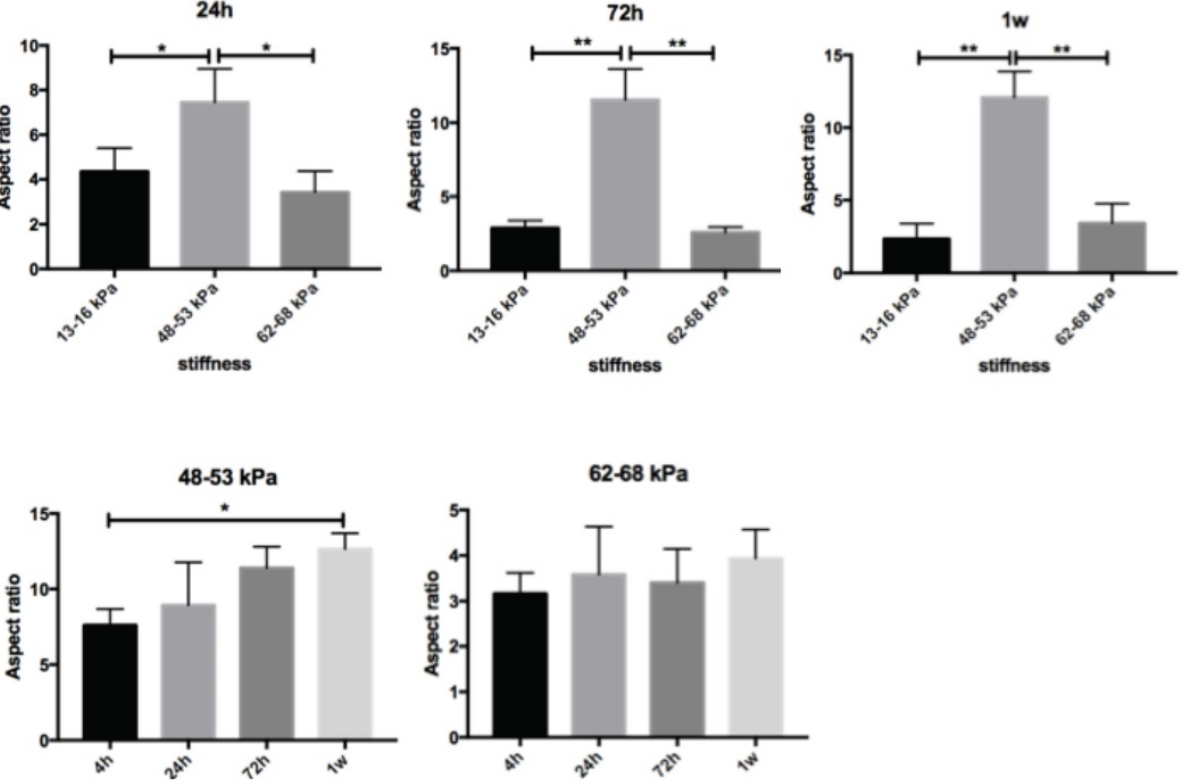

Figure 2. Morphology of BMMSCs on gels with various stiffnesses. (A) After BMMSCs were planted on the gels, the cells were analyzed with an inverted phase contrast microscope at $4 \mathrm{~h}-1 \mathrm{w}$. Scale bar $=20 \mu \mathrm{m}$. (B, C) Quantification of morphological changes versus stiffnesses at $4 \mathrm{~h}, 24 \mathrm{~h}, 72 \mathrm{~h}$ and $1 \mathrm{w}$. Cell aspect ratio was measured. $* \mathrm{P}<0.05$, $* * \mathrm{P}<0.01$. 


\section{Effect of matrix stiffness on adhesion and proliferation of BMMSCs}

To determine the functional impact of the matrix stiffness on BMMSCs culture, we investigated the adhesion and proliferation of BMMSCs by culturing them on polyacrylamide gels of increased stiffness. The percentage of adherent cells increased with elevated stiffnesses, reaching a maximal effect at 62-68 $\mathrm{kPa}$. The proliferation rate of BMMSCs was also monitored. As shown, cells in higher stiffnesses possessed a markedly elevated proliferative rate. The highest proliferation rate was obtained on the substrate with a modulus of $62-68 \mathrm{kPa}$, similar to the stiffness driving best adhesion. Cells displayed similar proliferation rates on substrates with stiffnesses of $48-53 \mathrm{kPa}$, and showed about $40 \%$ decrease in the proliferation rate on the softer substrate (13-16 kPa). Thus, cell adhesion and proliferation appear to be correlated with matrix stiffness (Fig. 3).

\section{Regulation of matrix stiffness on self-renewal gene expression}

To determine the effect of matrix stiffness on cell self-renewal, we cultured cells on different matrices for $4 \mathrm{~h}, 24 \mathrm{~h}, 72 \mathrm{~h}$ and 1 week to observe the expression levels of Sox 2 and Oct4. Sox 2 expression on $48-53 \mathrm{kPa}$ and $62-68 \mathrm{kPa}$ were lower than $13-16 \mathrm{kPa}$ at $4 \mathrm{~h}$; after $24 \mathrm{~h}$ Sox2 expression on $48-53 \mathrm{kPa}$ were highest; and gene expression were highest at $72 \mathrm{~h}$ but at 1 week Sox2 expression were highest on $48-53 \mathrm{kPa}$. Oct4 expression on 13-16 $\mathrm{kPa}$ were higher than $48-53 \mathrm{kPa}$ at $4 \mathrm{~h}$, and it has no significant differences at other time point among three different stiffness groups (Fig. 4A). Cells cultured on the $13-16 \mathrm{kPa}$ and $62-68 \mathrm{kPa}$, Sox2 expression were lower during $4 \mathrm{~h}$ to 1 week, in contrast, Sox2 expression were higher during 4 h to 1 week on the $48-53 \mathrm{kPa}$ (Fig. 4B). Oct4 expression were highest at $24 \mathrm{~h}$ than other point on $13-16 \mathrm{kPa}$ while it was highest at 1 week on $48-53 \mathrm{kPa}$. However, Oct4 expression has no significant differences on $62-68 \mathrm{kPa}$ during $4 \mathrm{~h}$ to 1 week (Fig. 4B).
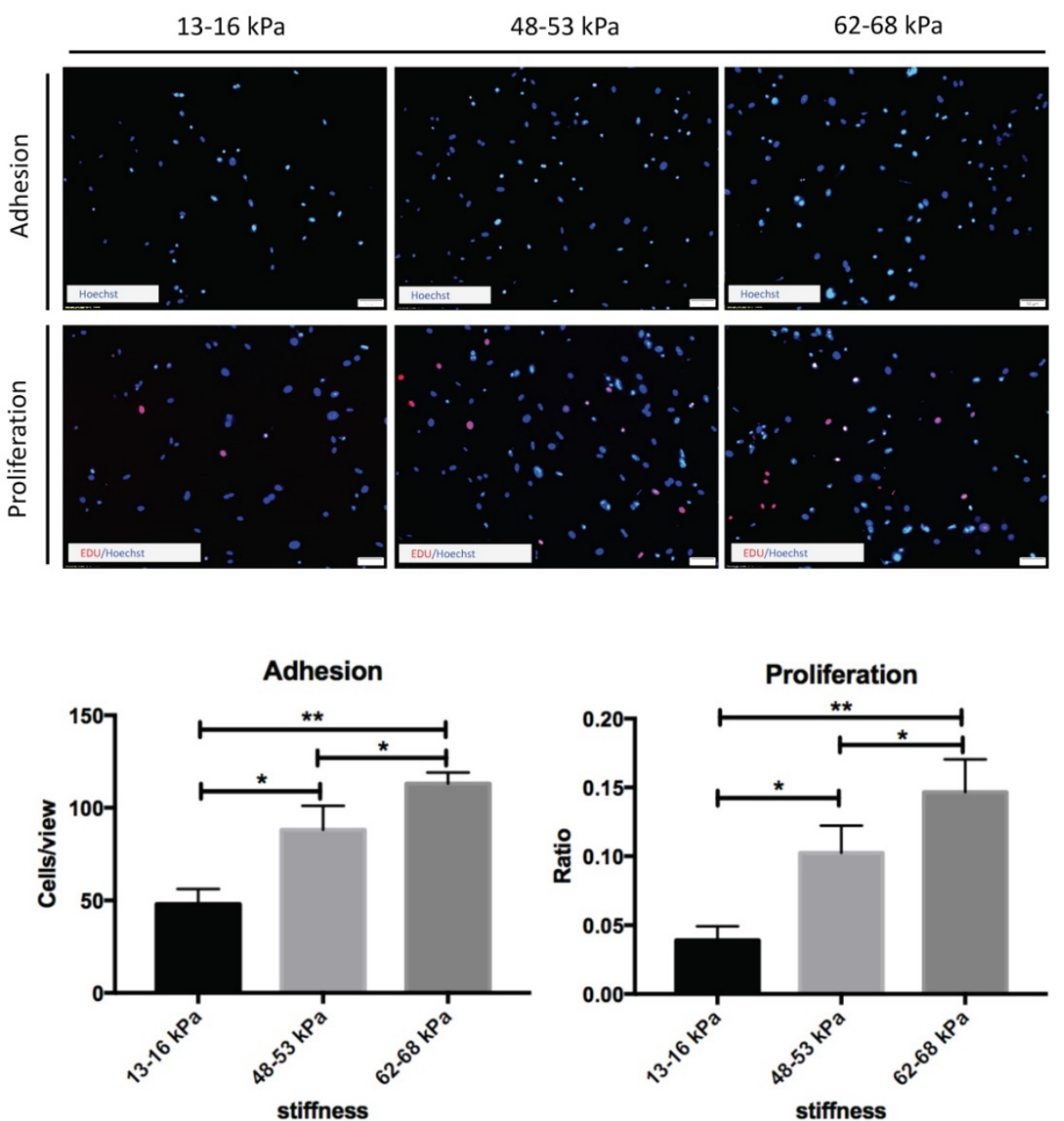

Figure 3. Regulation of BMMSCs adhesion and proliferation by matrix stiffness. Cell nuclei were counterstained with Hoechst (blue) 24 hours after planting to detect cells adhesion. Cell proliferation was assessed after 72 hours by EdU-based proliferation assay. Statistical analysis of results. $* \mathrm{P}<0.05$, $* * \mathrm{P}<0.01$. Scale bar $=$ $50 \mu \mathrm{m}$. 
A
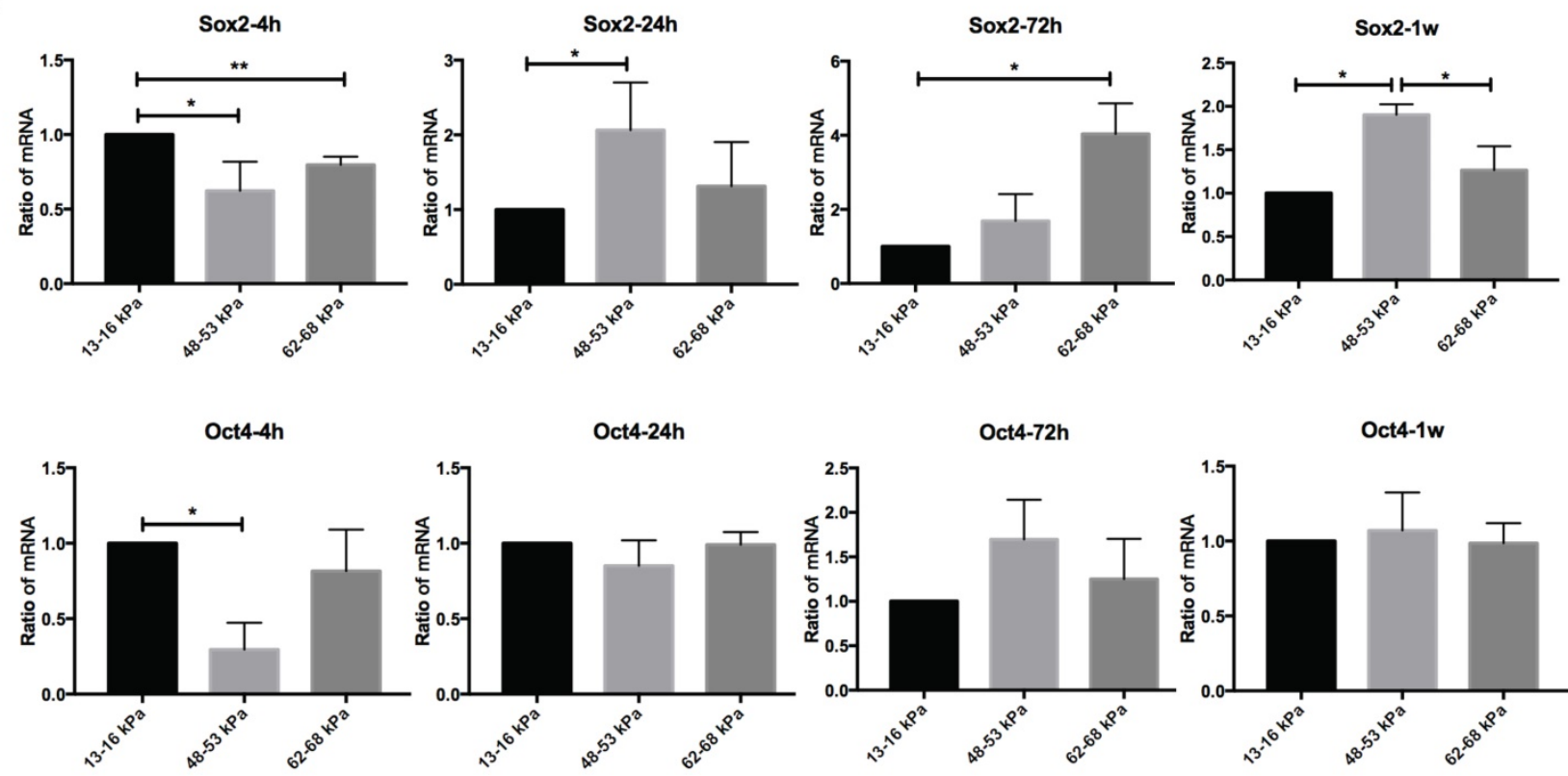

B
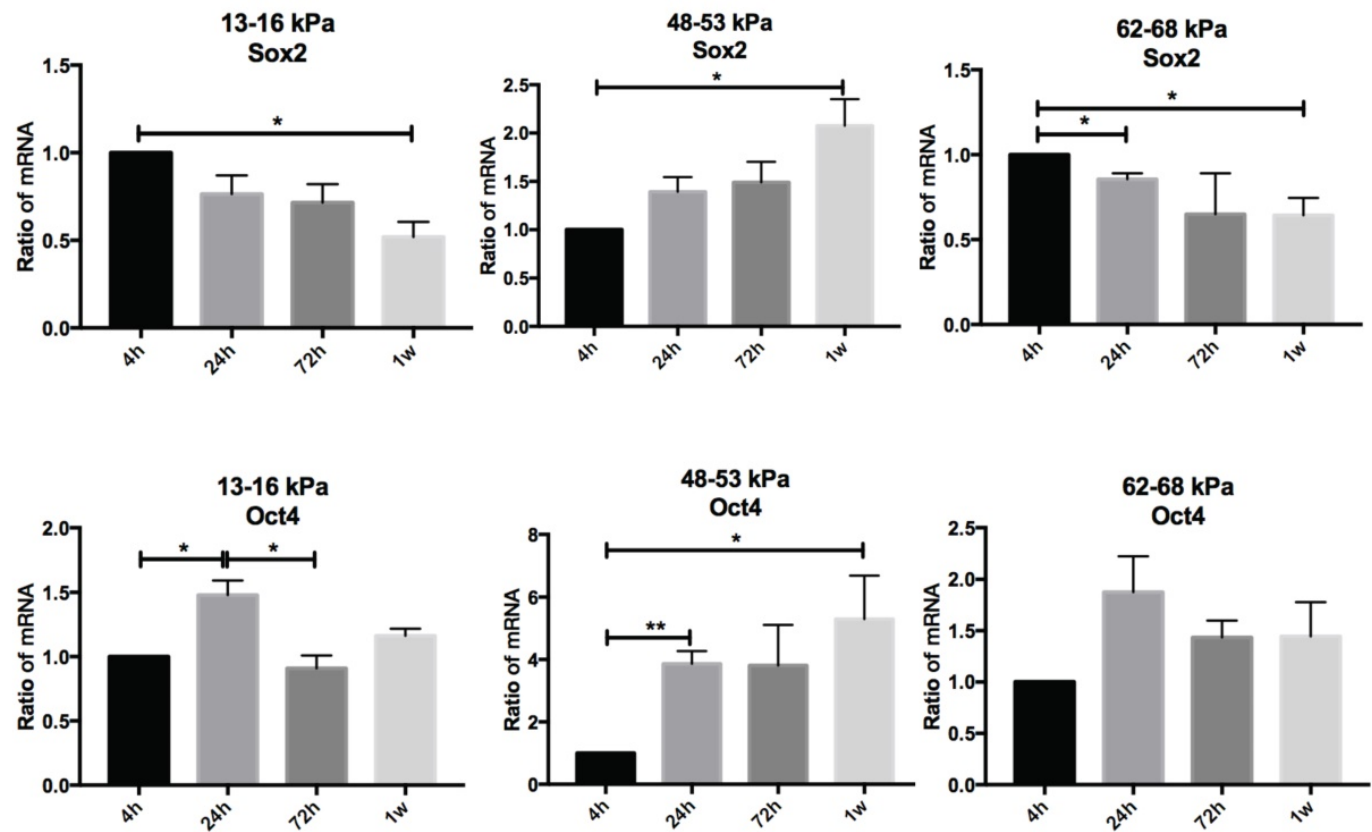

Figure 4. Osteogenic differentiation of BMMSCs on different matrix stiffnesses. (A) Sox 2 and Oct4 gene expressions on different matrices after $4 \mathrm{~h}, 24 \mathrm{~h}, 72 \mathrm{~h}$ and 1 week. (B) Sox2 and Oct4 gene expressions on 13-16 kPa, 48-53 kPa and 62-68 kPa at different time point. *P<0.05, $* * P<0.01$.

\section{Regulation of matrix stiffness on osteogenic gene expression}

To determine the influence of matrix stiffness on the differentiation of BMMSCs, we cultured the BMMSCs in osteogenic medium on polyacrylamide substrates with varying stiffnesses for $4 \mathrm{~h}, 24 \mathrm{~h}, 72 \mathrm{~h}$ and 1 week. We then used qPCR to determine the expression of osteogenic regulator RUNX2, early osteogenic markers COL1A1, Osteopontin, ALP and late stage markers Osteocalcin in the cells. It showed that the expressions of RUNX2 were highest at $4 \mathrm{~h}$ but significantly elevated on the gel with the stiffness of 62-68 $\mathrm{kPa}$ at 1 week. And COL1A1 were significantly increased on gel with $48-53 \mathrm{kPa}$ at $72 \mathrm{~h}$ while Osteocalcin were highest on the $62-68 \mathrm{kPa}$ at 1 week; ALP expression was highest on the $13-16 \mathrm{kPa}$ at $4 \mathrm{~h}$ but was significantly elevated on the $62-68 \mathrm{kPa}$ during $72 \mathrm{~h}$ to 1 week. Osteocalcin expression was highest on the $13-16 \mathrm{kPa}$ at $4 \mathrm{~h}$ and $24 \mathrm{~h}$, while it was highest on the $48-53 \mathrm{kPa}$ at 1 week (Fig. 5A). RUNX2 expression was lower from $4 \mathrm{~h}$ to 1 week on the $13-16 \mathrm{kPa}$ while higher from $4 \mathrm{~h}$ to 1 week. COL1A1 expression was higher 
from $4 \mathrm{~h}$ to $72 \mathrm{~h}$ on the $13-16 \mathrm{kPa}$ while higher from $4 \mathrm{~h}$ to 1 week on the $48-53 \mathrm{kPa}$ and $62-68 \mathrm{kPa}$. Osteopontin expression was lower from $4 \mathrm{~h}$ to 1 week on the 13-16 $\mathrm{kPa}$ and from $4 \mathrm{~h}$ to $24 \mathrm{~h}$ on the $48-53 \mathrm{kPa}$, while was higher at the $62-68 \mathrm{kPa}$ during $4 \mathrm{~h}$ to $72 \mathrm{~h}$. ALP expression was higher from $4 \mathrm{~h}$ to 1 week on the 13-16 $\mathrm{kPa}$ and it was higher from $4 \mathrm{~h}$ to $72 \mathrm{~h}$ but lower at 1 week on the 48-53 $\mathrm{kPa}$. However, ALP expression was higher at 1 week than $4 \mathrm{~h}$ on the $62-68 \mathrm{kPa}$. Osteocalcin expression was lower from $4 \mathrm{~h}$ to 1 week. There was no significant difference between other groups (Fig. 5B). After cultured on three groups for $72 \mathrm{~h}$ and 1 week, we stained Alizarin red $S$ to detect calcium deposits. It has shown that cells secrete calcium deposits on $62-68 \mathrm{kPa}$ at 1 week, while negative expression on the other groups (Fig. 5C). Collectively, these results support that culture on $62-68 \mathrm{kPa}$ induced MSCs differentiation into osteoblasts. These results showed cells on $62-68 \mathrm{kPa}$ differentiated to osteoblast.
A
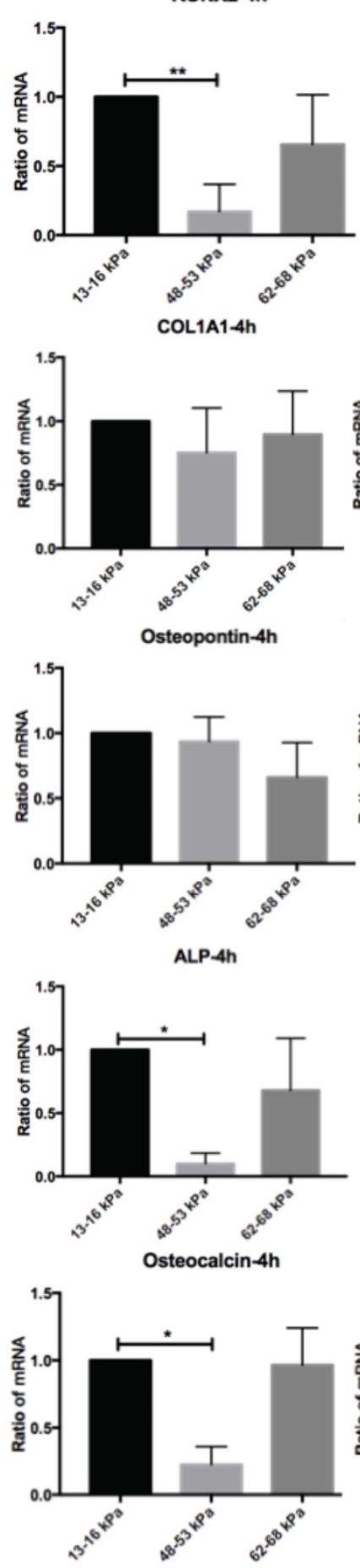

RUNX2-24h

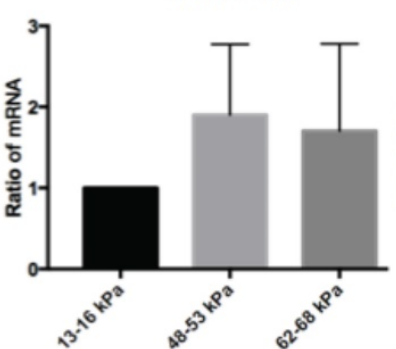

COL1A1-24h
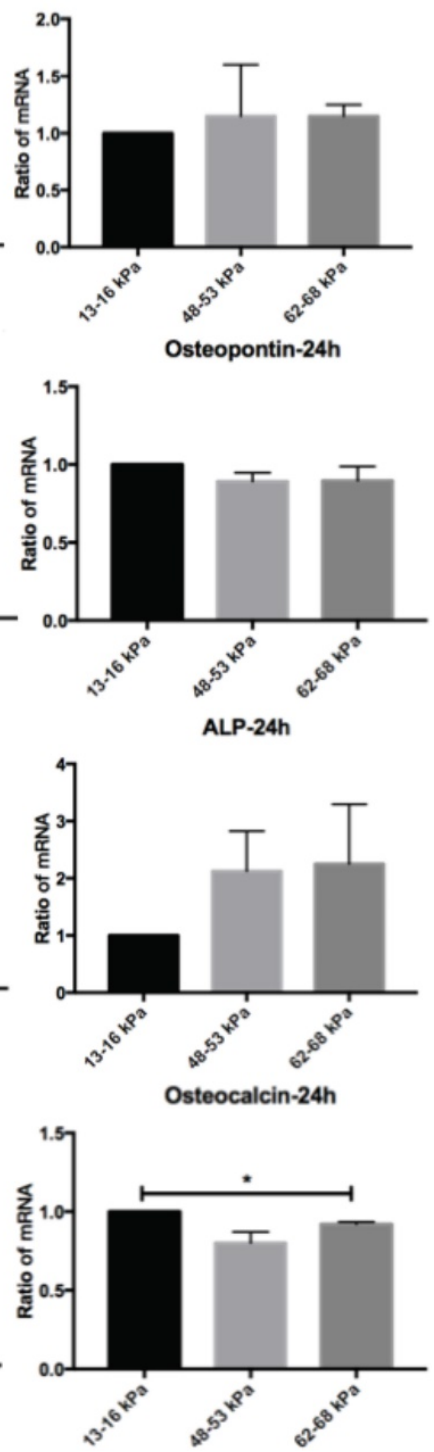

RUNX2-72h

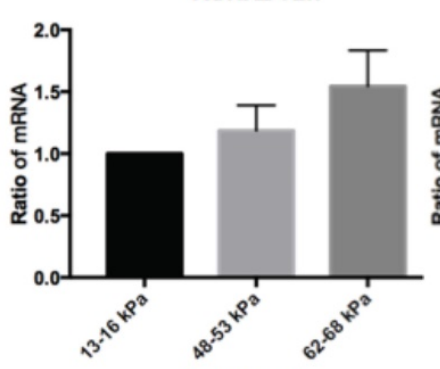

COL1A1-72h

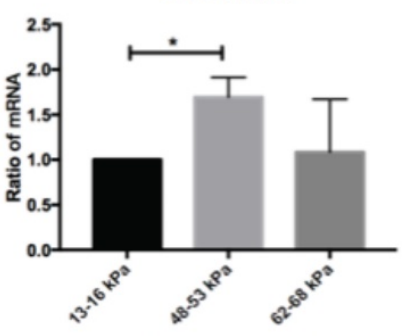

Osteopontin-72h
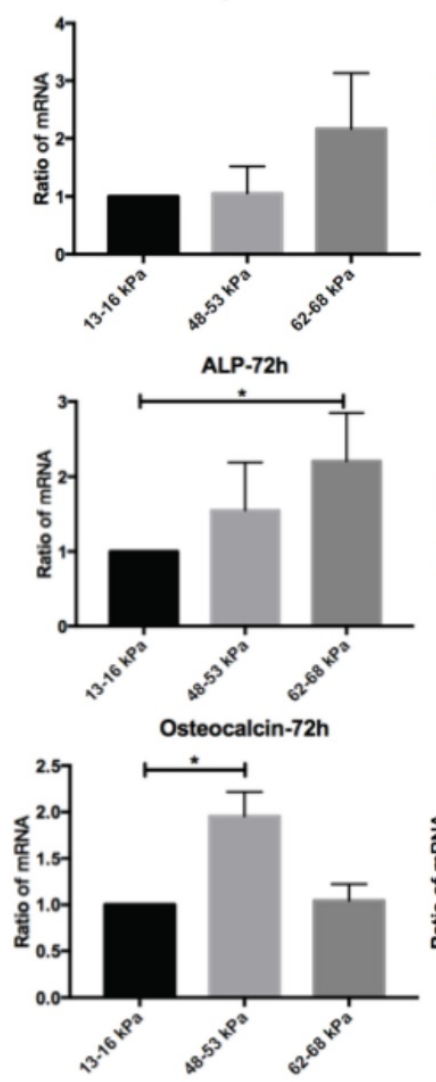

RUNX2-1w

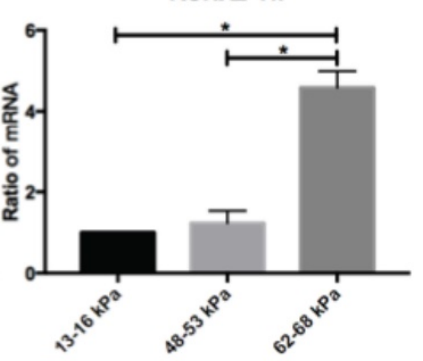

COL1A1-1W
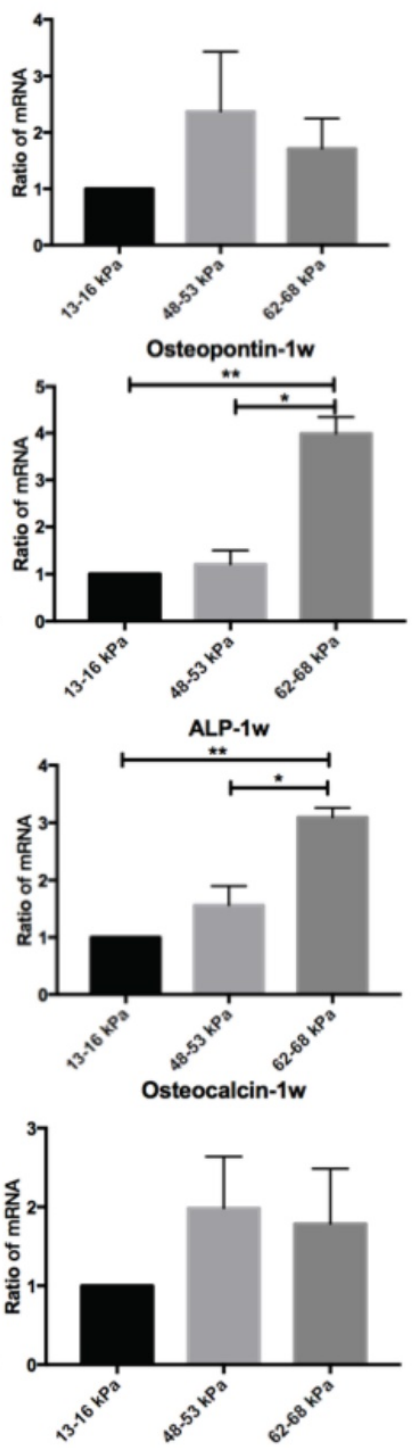

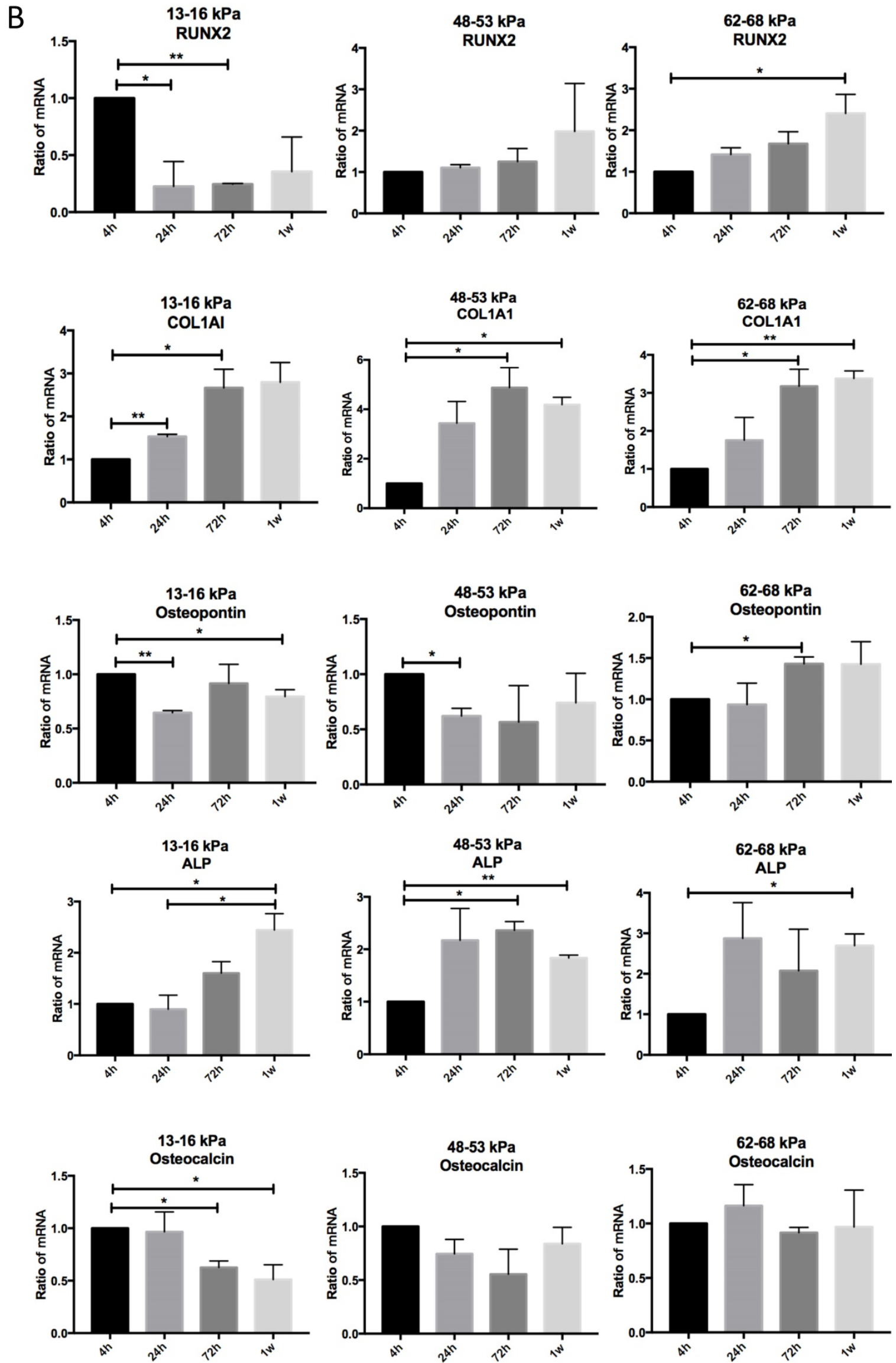
C

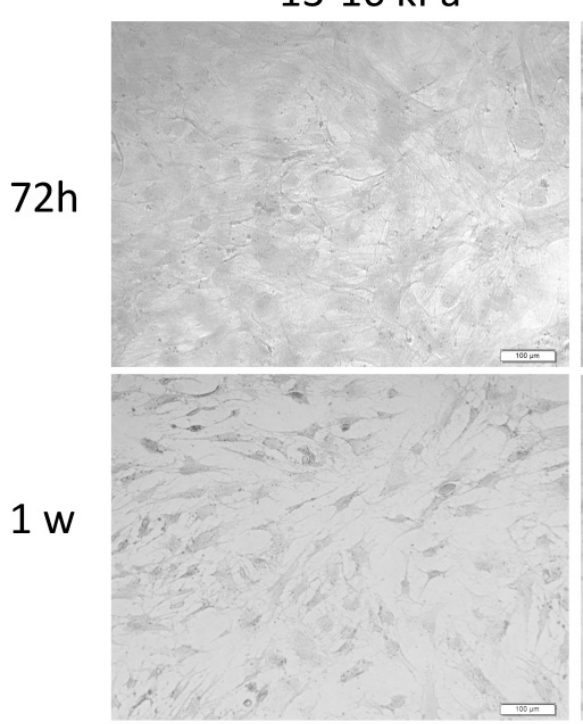

$48-53 \mathrm{kPa}$

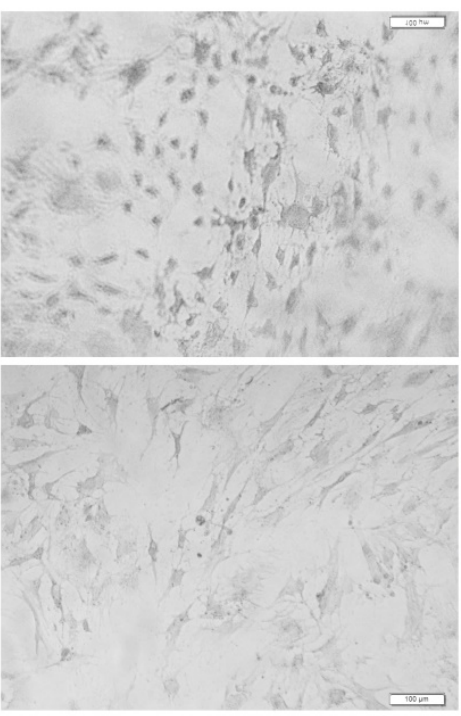

$62-68 \mathrm{kPa}$

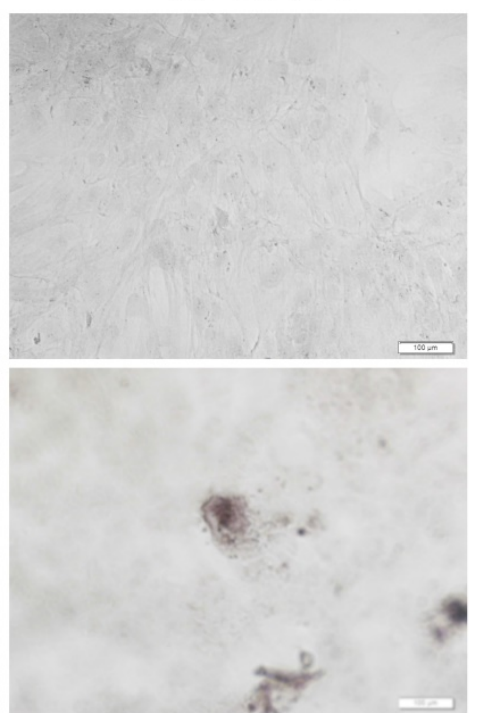

Figure 5. Osteogenic differentiation of BMMSCs on different matrix stiffnesses. (A)RUNX2, COL1A1, ALP, Osteopontin and Osteocalcin gene expressions on different matrices after $4 \mathrm{~h}, 24 \mathrm{~h}, 72 \mathrm{~h}$ and 1 week of differentiation. (B) RUNX2, COL1A1, ALP, Osteopontin and Osteocalcin gene expressions on 13-16 kPa, 48-53 $\mathrm{kPa}$ and $62-68 \mathrm{kPa}$ at different time point of differentiation. (C) After cultured on three groups for 1 week, we stained Alizarin red $\mathrm{S}$ to detect calcium deposits. Scale bar $=100 \mu \mathrm{m}$. $* \mathrm{P}<0.05, * * \mathrm{P}<0.01$.

\section{Discussion}

While numerous studies have involved in the role of matrix stiffness in mediating stem cell behavior, much less is known about the relationships between matrix stiffness and changes in cell morphology, adhesion, proliferation and differentiation. Here we used polyacrylamide hydrogels with independently modulated stiffness as an analogue of cellular microenvironment. We found that stiff substrate facilitated the proliferation of BMMSCs as compared with soft substrates. MSCs had a similar proliferation rate on medium substrates with modulus of $48-53 \mathrm{kPa}$ (Fig. 3). Proliferation of multiple cell types has been shown to be dependent on substrate stiffness. Smooth muscle cells [13] and fibroblasts [19] grow better on stiff flat substrates or stiff scaffolds, whereas adult neural stem cells proliferate most quickly on matrices of medium stiffness [20]. In line with prior works, thus, in MSCs level, our work adds another layer of evidence demonstrating the importance of stiff substrates in cellular proliferation. Similarly, a previous experiment showed that MSCs proliferated better at 3 and $15 \mathrm{kPa}$ than those on a $1 \mathrm{kPa}$ substrate as indicated by a $30 \%$ decrease in the proliferation rate on soft substrate, whereas no distinct difference was observed between 3 and $15 \mathrm{kPa}$ [21]. Therefore, it is possible that the relationship between stiffness and cell proliferation rate is nonlinear although increasing stiffness may preferentially enhance MSCs proliferation. MSCs probably respond to softer or stiffer matrix more strongly relative to intermediate modulus in terms of cell proliferation. Future studies should elucidate whether our results are universal for all sources of MSCs and explore the detailed dependence of MSCs proliferation on matrix stiffness.

Self-renewal of stem cell is regulated by transcription factors Sox2 [22] and Oct4 [23]. Oka reported that Sox 2 and Oct 4 expression were reduced with cells differentiation [24], and these events permit differentiation through a standard downregulation of Oct4-Sox2 mechanism [25]. We detected Sox2 and Oct4 expression of cells cultured on different stiffness matrices. Sox2 expression was significantly downregulated when cells cultured on 13-16 $\mathrm{kPa}$ and 62-68 $\mathrm{kPa}$ from $4 \mathrm{~h}$ to 1 week (Fig. 4B). While the expression of Sox 2 and Oct4 were significantly upregulated on $48-53 \mathrm{kPa}$, suggesting cells maintain self-renewal on $48-53 \mathrm{kPa}$. But it has been reported Oct4 is not necessary to main self-renewal because Lengner confirmed that deletion of Oct4 of MSCs can still maintain self-renewal[26]. Our results confirmed that Oct4 expression of MSCs on 62-68 kPa does not decrease during osteogenic differentiation from $4 \mathrm{~h}$ to 1 week.

We proved that osteogenic differentiation of MSCs preferentially occurred on stiffer substrate as indicated by high expression of osteogenic markers RUNX2, ALP and Osteopontin (Fig. 5), which is consistent with previous reports [27-29]. Yet, there was no obvious increase in the expression of other osteogenic genes including COL1A1 and Osteocalcin, both of which are directly regulated by RUNX2 [30, 
31]. A plausible explanation is that there may be a commitment/growth-dependent effect for MSCs. When osteogenic commitment is initiated in MSCs, cells are still actively proliferating. Thus, the differentiation induced by RUNX2 may be impeded due to the proliferation. The downstream targets of RUNX2, such as collagen type I and osteocalcin, may retain unchanged in a certain time [32]. It may weaken the effect and elevate COL1A1 and osteocalcin expression if the time exposed to the induction for the cells is sufficient. Moreover, although higher stiffness of $62-68 \mathrm{kPa}$ drove osteoblast differentiation, the stiffnesses of $48-53 \mathrm{kPa}$, which are comparable to those in pre-mineralized bone $(>30 \mathrm{kPa})$, induced the formation of spindle-shaped cells similar to myoblasts (Fig. 2A). Generally, these results are consistent with Engler's work showing that MSCs undergo the osteogenesis at $25-40 \mathrm{kPa}$, whereas intermediate polyacrylamide gels of 8-17 $\mathrm{kPa}$ favour myogenic differentiation [6]. Interestingly, it was reported that MSCs were also engaged in osteogenic differentiation in soft chondroitin sulfate-collagen scaffolds of 1.5 $\mathrm{kPa}$ [33]. These phenomena can be attributable to a few reasons. Synthetic matrix materials with a similar crosslinking degree may bear a distinct modulus due to lack of an effectively unified representation and measurement. The testing data for stiffness only provide the bulk modulus of the matrix material rather than the local mechanical stiffness, which is highly likely to change during cellular processes. Additionally, different protein coatings to improve cell-adhesive properties or biochemical compositions of matrix used in studies may interact with matrix and modify the optimal modulus that is determined by stiffness in stem cell culture [34, 35].

Consistent with other studies [6, 36], we demonstrated that MSCs adopted different morphologies in response to varying substrate stiffnesses (Fig. 2). Notably, a higher proliferation rate and osteogenic commitment on stiff matrices were accompanied by an increase of cell spreading and polygonal morphology. Cell shapes have been shown to involve in cell proliferation and commitment [37]. The increase in endothelial cell spreading results in an escalation of nuclear volume and a greater proportion of cells in the S phase of cell cycle [38]. McBeath et al. [39] utilized micro patterning to control MSCs shapes and demonstrated that flatten, spread cells prefer to differentiate into osteoblasts, whereas unspread, round cells develop into adipocytes. Furthermore, it was found that the shape-dependent control of stem cell proliferation and differentiation is mediated by actin-myosin-generated tension through Rho signalling [40, 41]. Thus, matrix stiffness may influence MSCs proliferation and differentiation process through changing cell shapes.

We found that cell adhesion was dependent upon matrix stiffness (Fig. 3). Maximal expression of osteogenic genes was observed in MSCs cultured on stiffest substrates, which also promoted cell adhesion. The finding pointed to a direct correlation between MSC adhesion and the induction of lineage specification. In fact, suspension cells are less capable to sense and interpret the signals from the close mechanical environment [42]. In a stark contrast, during the stiffness sensing process, cells adhere and apply traction force on a substrate, and respond to the resistance from substrates, which may activate a cascade of signalling events vital to cell behaviors [43, 44]. It has been shown that MSCs may be driven into differentiation by a tight or loose attachment depending on the stiffness of the substrate [6]. The high percentage of adhesion on stiff substrate probably promotes the differentiation of MSCs towards osteogenic lineage. Moreover, cell proliferation was increasing very similarly to cell adhesion with the enhancement of stiffness in the substrates. Thus it is likely that a high proliferation rate of MSCs boosts the osteogenesis on stiff matrices regulated by cell adhesion as cell proliferation has been proven to be effectors of differentiation both in 2D and 3D microenvironments $[45,46]$.

In the current study, we demonstrated that matrix stiffness modulates morphology, adhesion, proliferation, and differentiation in MSCs in 2D culture. However, the 2D cell culture model is unable to fully recapitulate the complex of the microenvironment in vivo. The stiffness of 3D matrix may overcome the disadvantage and mimic the microenvironment in vivo. For example, it was reported that MSCs maintain a spherical morphology when these cells are encapsulated in 3D polyethylene glycol hydrogels of stiffness ranging from 0.2 to 59 $\mathrm{kPa}$ [47]. Additionally, matrix stiffness is only one of the factors determining the stem cell fate. Additional micro environmental signals may work in a manner correlated with stiffness. Thus, in future researches, the synthetic effects of matrix stiffness, ligands, soluble factors, and cell-cell contact on stem cell behaviours should be performed in truly 3D stem cell niche.

In summary, our results support the hypothesis that matrix stiffness influences stem cell proliferation and differentiation via the alteration of cell morphology, adhesion, and cell proliferation. These findings are of great significance for the design of biomaterials with appropriate stiffness in tissue engineering and for harnessing the regenerative potential of stem cells although the molecular mechanism by which stem cell differentiation is 
regulated by matrix stiffness requires further studies.

\section{Supplementary Material}

Supplementary figures.

http://www.medsci.org/v15p0257s1.pdf

\section{Acknowledgements}

This work was supported by the State Key Development Program for Basic Research of China (Grant No. 2011CB606201), the National Natural Science Foundation of China (Grant No. 31201052, 81572139), and Jilin Province Science and Technology Development Program for Young Scientists Fund (Grant No. 20150520036JH).

\section{Competing Interests}

The authors have declared that no competing interest exists.

\section{References}

1. Das M, Sundell IB, Koka PS. Adult mesenchymal stem cells and their potency in the cell-based therapy. Journal of stem cells. 2013; 8: 1-16.

2. Slavin S, Brodie C. The Use of Bone Marrow Derived Mesenchymal Stromal Cells for Treatment of Patients with Multiple Sclerosis and Neurodegenerative Disorders - Achievements and Future Goals. Biol Blood Marrow Tr. 2012; 18: S257-S8.

3. Parekkadan B, Milwid JM. Mesenchymal Stem Cells as Therapeutics. Annu Rev Biomed Eng. 2010; 12: 87-117.

4. Lv H, Li L, Zhang Y, Chen Z, Sun M, Xu T, et al. Union is strength: matrix elasticity and microenvironmental factors codetermine stem cell differentiation fate. Cell Tissue Res. 2015.

5. Guilak F, Cohen DM, Estes BT, Gimble JM, Liedtke W, Chen CS. Control of stem cell fate by physical interactions with the extracellular matrix. Cell stem cell. 2009; 5: 17-26.

6. Engler AJ, Sen S, Sweeney HL, Discher DE. Matrix elasticity directs stem cell lineage specification. Cell. 2006; 126: 677-89.

7. Kasten A, Muller P, Bulnheim U, Groll J, Bruellhoff K, Beck U, et al. Mechanical Integrin Stress and Magnetic Forces Induce Biological Responses in Mesenchymal Stem Cells Which Depend on Environmental Factors. J Cell Biochem. 2010; 111: 1586-97.

8. Yeung T, Georges PC, Flanagan LA, Marg B, Ortiz M, Funaki M, et al. Effects of substrate stiffness on cell morphology, cytoskeletal structure, and adhesion. Cell Motil Cytoskel. 2005; 60: 24-34

9. Lo CM, Wang HB, Dembo M, Wang YL. Cell movement is guided by the rigidity of the substrate. Biophysical Journal. 2000; 79: 144-52.

10. Smith JT, Elkin JT, Reichert WM. Directed cell migration on fibronectin gradients: Effect of gradient slope. Exp Cell Res. 2006; 312: 2424-32.

11. Giannone G, Sheetz MP. Substrate rigidity and force define form through tyrosine phosphatase and kinase pathways. Trends in cell biology. 2006; 16: 213-23.

12. Subramanian A, Lin HY. Crosslinked chitosan: Its physical properties and the effects of matrix stiffness on chondrocyte cell morphology and proliferation. Journal of Biomedical Materials Research Part A. 2005; 75A: 742-53.

13. Peyton SR, Raub CB, Keschrumrus VP, Putnam AJ. The use of poly(ethylene glycol) hydrogels to investigate the impact of ECM chemistry and mechanics on smooth muscle cells. Biomaterials. 2006; 27: 4881-93.

14. Pelham RJ, Jr., Wang Y. Cell locomotion and focal adhesions are regulated by substrate flexibility. Proc Natl Acad Sci U S A. 1997; 94: 13661-5.

15. Lee $K$, Chen QK, Lui C, Cichon MA, Radisky DC, Nelson CM. Matrix compliance regulates Rac1b localization, NADPH oxidase assembly, and epithelial-mesenchymal transition. Mol Biol Cell. 2012; 23: 4097-108.

16. Wang YL, Pelham RJ, Jr. Preparation of a flexible, porous polyacrylamide substrate for mechanical studies of cultured cells. Methods in enzymology. 1998; 298: 489-96.

17. Funahashi $\mathrm{H}$, Ekwall $\mathrm{H}$, Rodriguez-Martinez $\mathrm{H}$. Zona reaction in porcine oocytes fertilized in vivo and in vitro as seen with scanning electron microscopy. Biology of reproduction. 2000; 63: 1437-42.

18. Shih YR, Tseng KF, Lai HY, Lin CH, Lee OK. Matrix stiffness regulation of integrin-mediated mechanotransduction during osteogenic differentiation of human mesenchymal stem cells. J Bone Miner Res. 2011; 26: 730-8.

19. Hadjipanayi E, Mudera V, Brown RA. Close dependence of fibroblast proliferation on collagen scaffold matrix stiffness. J Tissue Eng Regen M. 2009; 3: $77-84$
20. Leipzig ND, Shoichet MS. The effect of substrate stiffness on adult neural stem cell behavior. Biomaterials. 2009; 30: 6867-78.

21. Park JS, Chu JS, Tsou AD, Diop R, Tang Z, Wang A, et al. The effect of matrix stiffness on the differentiation of mesenchymal stem cells in response to TGF-beta. Biomaterials. 2011; 32: 3921-30.

22. Singh S, Trevino J, Bora-Singhal N, Coppola D, Haura E, Altiok S, et al. EGFR/Src/Akt signaling modulates Sox2 expression and self-renewal of stem-like side-population cells in non-small cell lung cancer. Mol Cancer. 2012; 11: 73 .

23. Jang HS, Hong YJ, Choi HW, Song H, Byun SJ, Uhm SJ, et al. Changes in Parthenogenetic Imprinting Patterns during Reprogramming by Cell Fusion. PLoS One. 2016; 11: e0156491.

24. Oka M, Moriyama T, Asally M, Kawakami K, Yoneda Y. Differential role for transcription factor Oct4 nucleocytoplasmic dynamics in somatic cell reprogramming and self-renewal of embryonic stem cells. J Biol Chem. 2013; 288: 15085-97.

25. Batra VK, Shock DD, Beard WA, McKenna CE, Wilson SH. Binary complex crystal structure of DNA polymerase beta reveals multiple conformations of the templating 8-oxoguanine lesion. Proc Natl Acad Sci U S A. 2012; 109: 113-8.

26. Lengner CJ, Camargo FD, Hochedlinger K, Welstead GG, Zaidi S, Gokhale S, et al. Oct4 expression is not required for mouse somatic stem cell self-renewal. Cell Stem Cell. 2007; 1: 403-15.

27. Zouani OF, Kalisky J, Ibarboure E, Durrieu MC. Effect of BMP-2 from matrices of different stiffnesses for the modulation of stem cell fate. Biomaterials. 2013; 34: 2157-66.

28. Colley HE, Mishra G, Scutt AM, McArthur SL. Plasma Polymer Coatings to Support Mesenchymal Stem Cell Adhesion, Growth and Differentiation on Variable Stiffness Silicone Elastomers. Plasma Process Polym. 2009; 6: 831-9.

29. Trappmann B, Gautrot JE, Connelly JT, Strange DG, Li Y, Oyen ML, et al. Extracellular-matrix tethering regulates stem-cell fate. Nat Mater. 2012; 11: 642-9.

30. Takazawa Y, Tsuji K, Nifuji A, Kurosawa H, Ito Y, Noda M. An osteogenesis-related transcription factor, core-binding factor A1, is constitutively expressed in the chondrocytic cell line TC6, and its expression is upregulated by bone morphogenetic protein-2. J Endocrinol. 2000; 165: 579-86.

31. Ducy P, Zhang R, Geoffroy V, Ridall AL, Karsenty G. Osf2/Cbfa1: a transcriptional activator of osteoblast differentiation. Cell. 1997; 89: 747-54.

32. Lv H, Li L, Sun M, Zhang Y, Chen L, Rong Y, et al. Mechanism of regulation of stem cell differentiation by matrix stiffness. Stem Cell Res Ther. 2015; 6: 103.

33. Murphy CM, Matsiko A, Haugh MG, Gleeson JP, O'Brien FJ. Mesenchymal stem cell fate is regulated by the composition and mechanical properties of collagen-glycosaminoglycan scaffolds. J Mech Behav Biomed. 2012; 11: 53-62.

34. Rowlands AS, George PA, Cooper-White JJ. Directing osteogenic and myogenic differentiation of MSCs: interplay of stiffness and adhesive ligand presentation. Am J Physiol Cell Physiol. 2008; 295: C1037-44.

35. Lee J, Abdeen AA, Zhang D, Kilian KA. Directing stem cell fate on hydrogel substrates by controlling cell geometry, matrix mechanics and adhesion ligand composition. Biomaterials. 2013; 34: 8140-8.

36. Ghosh K, Pan Z, Guan E, Ge SR, Liu YJ, Nakamura T, et al. Cell adaptation to a physiologically relevant ECM mimic with different viscoelastic properties. Biomaterials. 2007; 28: 671-9.

37. Kumar G, Waters MS, Farooque TM, Young MF, Simon CG, Jr. Freeform fabricated scaffolds with roughened struts that enhance both stem cell proliferation and differentiation by controlling cell shape. Biomaterials. 2012; 33: 4022-30.

38. Roca-Cusachs P, Alcaraz J, Sunyer R, Samitier J, Farre R, Navajas D. Micropatterning of single endothelial cell shape reveals a tight coupling between nuclear volume in G1 and proliferation. Biophysical Journal. 2008; 94: 4984-95.

39. McBeath R, Pirone DM, Nelson CM, Bhadriraju K, Chen CS. Cell shape, cytoskeletal tension, and RhoA regulate stem cell lineage commitment. Developmental cell. 2004; 6: 483-95.

40. Assoian RK, Klein EA. Growth control by intracellular tension and extracellular stiffness. Trends Cell Biol. 2008; 18: 347-52.

41. Zajac AL, Discher DE. Cell differentiation through tissue elasticity-coupled, myosin-driven remodeling. Curr Opin Cell Biol. 2008; 20: 609-15.

42. Levy L, Broad S, Diekmann D, Evans RD, Watt FM. beta1 integrins regulate keratinocyte adhesion and differentiation by distinct mechanisms. Mol Biol Cell. 2000; 11: 453-66.

43. De Santis G, Lennon AB, Boschetti F, Verhegghe B, Verdonck P, Prendergast PJ. How Can Cells Sense the Elasticity of a Substrate? An Analysis Using a Cell Tensegrity Model. European cells \& materials. 2011; 22: 202-13.

44. Discher DE, Janmey P, Wang YL. Tissue cells feel and respond to the stiffness of their substrate. Science. 2005; 310: 1139-43

45. Hsiong SX, Carampin P, Kong HJ, Lee KY, Mooney DJ. Differentiation stage alters matrix control of stem cells. Journal of Biomedical Materials Research Part A. 2008; 85A: 145-56.

46. Comisar WA, Kazmers NH, Mooney DJ, Linderman JJ. Engineering RGD nanopatterned hydrogels to control preosteoblast behavior: A combined computational and experimental approach. Biomaterials. 2007; 28: 4409-17.

47. Parekh SH, Chatterjee K, Lin-Gibson S, Moore NM, Cicerone MT, Young MF, et al. Modulus-driven differentiation of marrow stromal cells in 3D scaffolds that is independent of myosin-based cytoskeletal tension. Biomaterials. 2011; 32: $2256-64$ 